Reprod. Nutr. Dévelop., 1980, 20 (3 A), 687-698.

\title{
Effects of intense abdominal irradiation at a high dose (1 100 rd) on gastric secretion and apparent feed digestibility in swine
}

\author{
par F. DABURON, Y. TRICAUD, D. BOURHOVEN \\ Commissariat d l'Energie atomique, \\ Institut de Protection ef de sareté nucléaire, \\ Département de Protection-Service de Radiopathologie et de Toxicologie Expérimentale \\ Laboratoire de Radiobiologie Appliquée, \\ C.N.R.Z., 78350 Jouy-en-Josas, France.
}

Summary. Gastric and pancreatic secretions were studied in 8 pigs irradiated at $1100 \mathrm{rd}$ on the hind-half of the body.

Irradiation always caused achlorhydria lasting at least 10 days. Recovery was partial and variable; rehabilitation or the persistence of anorexia closely depended on recovery. Stomachal mucosa response to gastrin stimulation was very disturbed.

Impairment of the pancreatic endocrine function led to progressive diabetes ; the exocrine function also seemed to decrease with the survival time.

\section{Introduction.}

In studying the consequences of intense abdominal irradiation, accent has usually been put on intestinal impairment because of the high radiosensitivity of crypt stem cells and the rapid renewal of the mucosal epithelium, which do affect the intensity and precocity of intestinal lesions.

When swine were irradiated at 1100 rd on the hind-half of the body (Daburon ef al., 1975, 1978), intestinal recovery usually led to partial mucosal atrophy, permitting middle-term survival (several months). However, some animals showed more or less long phases of anorexia which were sometimes definitive, causing death due to a state of general denutrition and extreme cachexia.

In view of this symptomatology, we decided to study, under irradiation conditions similar to those of the previous work, the secretory capacities of the stomach and pancreas, giving special attention to endocrine secretion.

The functional and lesional effects of radiation on the stomach were first reported a long time ago, and Rubin and Casarett compiled a very complete bibliography in 1968a. The most striking fact is the time-lag between immediate functional disorders (gastric emptying and inhibition of secretions) and mucosal lesions which, at the doses we used, were more discrete and appeared much later (during the second week).

There are few data on the pancreas (Rubin and Casarett, 1968b), and they are 
often conflicting as concerns organ radiosensitivity. However, Corring ef al. (1975) studying swine, showed the effects on exocrine secretion of a single irradiation (at 600 and at $800 \mathrm{rd}$ ) of the hind-half of the body.

\section{Material and methods}

A. - Animals. Eight adult Corsican pigs, weighing a mean $61 \mathrm{~kg}(47-82 \mathrm{~kg})$ were used. Before the experiments, they were fitted with two indwelling catheters (Silastic ND), one of $2 \times 4 \mathrm{~mm}$ in the jugular vein and one of $3 \times 5 \mathrm{~mm}$ in the stomach.

B. - Irradiation conditions (fig. 1). The conscious pigs, suspended in a sling, were irradiated using eight sources of about 1000 curies of ${ }^{60} \mathrm{Co}$, placed four by four on each side of the animal; two lead plates $75 \times 45 \mathrm{~cm}$ and $7.5 \mathrm{~cm}$ thick, one on either side of the sling, protected the fore-part of the animal $2-3 \mathrm{~cm}$ in front of the xiphoid process. The irradiation dose was 1100 rads at the body midline, and dose rate at the skin was about $45 \mathrm{R} / \mathrm{min}$ (or about $30 \mathrm{rd} / \mathrm{min}$ at the body midline).

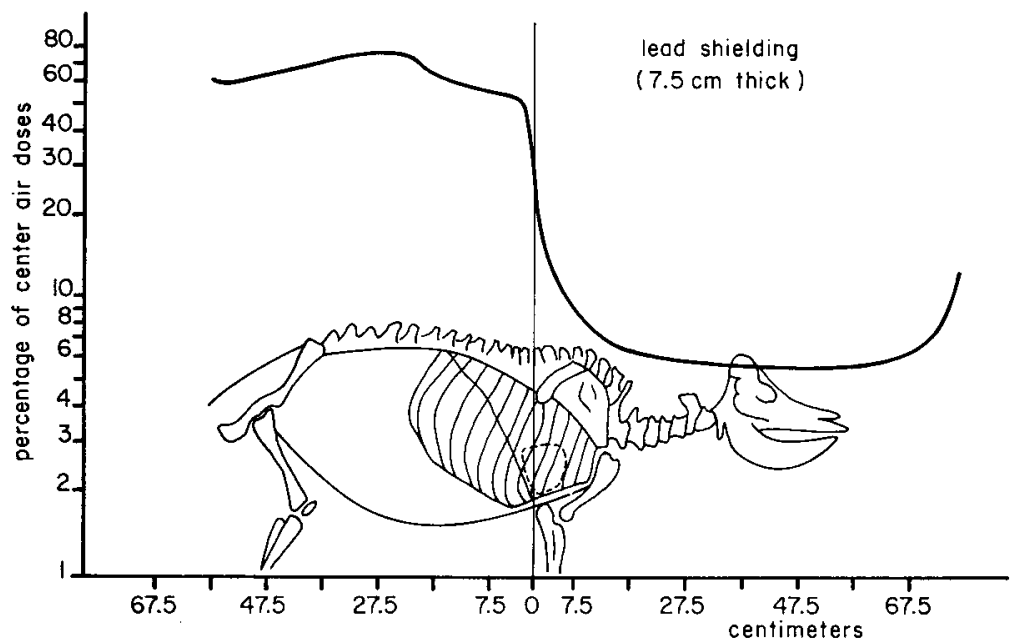

FIG. 1. - Distribution of air irradiation dose in percentage of the center dose of 8 unprotected sources.

Under these conditions, about 10 p. 100 of the live bone marrow was conserved, which is sufficient for protection from the hematological syndrome.

C. - Functional exploration of gastric and pancreatic secretions. Gastric and pancreatic samples were taken from the controls before irradiation (D 0$)$ and then at $D 3-4$, D 10-12, D 16-18, D 21-22, D 26-28, D 30-32, D 38-46 after irradiation.

1) Gastric exploration.

a) Gastric samples were obtained by pumping the indwelling catheter, according to the technique of Zeitoun (1965) and Devaux (1970), using animals maintained on a hydric diet for $24 \mathrm{hrs}$ before. The gastric liquid was collected in ice-cooled flasks for six consecutive 30 -min periods, i. e. during a total of $3 \mathrm{hrs}$. 
The first sample was discarded. After the second one (No. 2), i.e. $1 \mathrm{hr}$, the animals were given an injection of $6 \mu \mathrm{g} / \mathrm{kg}$ of synthetic pentagastrin (Peptavlon, ICl Pharma). Four successive samples (No. 3-6) were then collected in the following $2 \mathrm{hrs} ; \mathrm{pH}$ and acidity were measured immediately. The rest of the samples were frozen and stored at $-20^{\circ} \mathrm{C}$ for other assays.

b) Gastric juice assay.

1. - $\mathrm{pH}$, total (up to $\mathrm{pH} 8.5$ ) and free (return assay back to $\mathrm{pH} 3.5$ ) acidity were determined by the method of Lambling (1956).

2. - We wished to use a more precise method for measuring bile salts than the characteristic reactions (Pettenkoffer or Gmelin) ; in fact, duodenal reflux is common in swine and the gastric juices are always yellow-colored (Jacquot ef al., 1958).

We thus used the method of Szalkowski and Mader (1952) which permits salicyclic aldehyde assay of deoxycholic acid after extraction with a methylic acetonealcohol mixture. The bile of swine is poor in deoxycholic acid (Bergstrom ef al., 1959), but there are interactions with other bile acids (Haslewood, 1964) (chenodeoxycholic acid). Thus, the method used to determine the proportion of bile acids in the gastric juices was only semi-quantitative, and the results were obtained in deoxycholic acid equivalent.

3. - Sodium and potassium were assayed by flame spectrophotometry after acid mineralization.

4. - Pepsin was assayed by the method of Klotz and Duvall (1957) using ${ }^{131}$ iodinelabelled albumin ; the Merck pepsin reference was 1 Anson $\mathrm{mU}$ per $\mathrm{mg}$.

5. - DNA was assayed in the presence of sialic acid by the method of Croft and Lubran (1964).

2) Pancreatic exploration

a) The pancreatic endocrine function was studied by tests for hyper and hypoglycemia. Hyperglycemia was induced by an intravenous injection of $0.15 \mathrm{~g}$ of glucose per $\mathrm{kg}$; blood samples were taken $0,2,7,15,30,60$ and 120 min after injection. The same procedure was followed for hypoglycemia induced by the intravenous injection of tolbutamine (Dolipol, (B)) $\left(1 \mathrm{~g}\right.$ per $\left.1.73 \mathrm{~m}^{2 *}\right)$.

Blood sugar (GOD method) and insulin (INSIK-1-CIS radioimmunological assay) were measured in both tests.

b) The pancreatic exocrine function was estimated only by the nutritional balances (proteins, minerals) and the ratios of soluble to total protein in the feces, taking into account previous data (Daburon et al., 1978).

3) Gastrinemia.

We studied the effect of vagal stimulation, due to tolbutamine-induced hypoglycemia, on blood gastrin content (Pe Thein and Schofield, 1959).

Gastrinemia was defermined by radioimmunology (CIS-GASK kit).

* Swine body surface $\left(\mathrm{m}^{2}\right)=9.9^{3} \sqrt{\mathrm{P}^{2}}$ liveweight in grams. 


\section{Results.}

A. - Survival. The mean survival rate of the 8 animals was 53 days (extreme values: 7 and 73 days). Two animals died from endocarditis and nephritis, 2 from radiological lesions in the intestine, and 4 due to persistant anorexia causing a state of denutrition and extreme cachexia.

No hematological problems were encountered with a minimum of 5000 leucocyfes $/ \mathrm{mm}^{3}$ on day 5 and $150-180000$ platelets $/ \mathrm{mm}^{3}$ between days 10 and 20 .

B. - Nutrition. The animals were put under intravenous perfusion* (Daburon et al., 1979) for 5 to 7 days between days 3 and 10. When they did not begin to eat pelleted food normally, liquid food was perfused continually into the intestine (3-4 I/day; $900 \mathrm{kcal} / \mathrm{l}$ ) through the indwelling stomachal catheter for 4 to 5 days.

C. - Gastric exploration. Seven out of 8 animals presenfed achlorhydria on day 3, apparently analogous to the cellular achlorhydria described by Lambling : $\mathrm{pH}$, total acidity and buffer capacity (mean of 4 samples ; $3-6$ ) remained constant throughout the duration of the test.

After pentagastrin, the ratio $p$ of the mean buffer capacity of samples 3 and 4 to sample 2 buffer capacity, i. e. after and before pentagastrin, was $>1$.

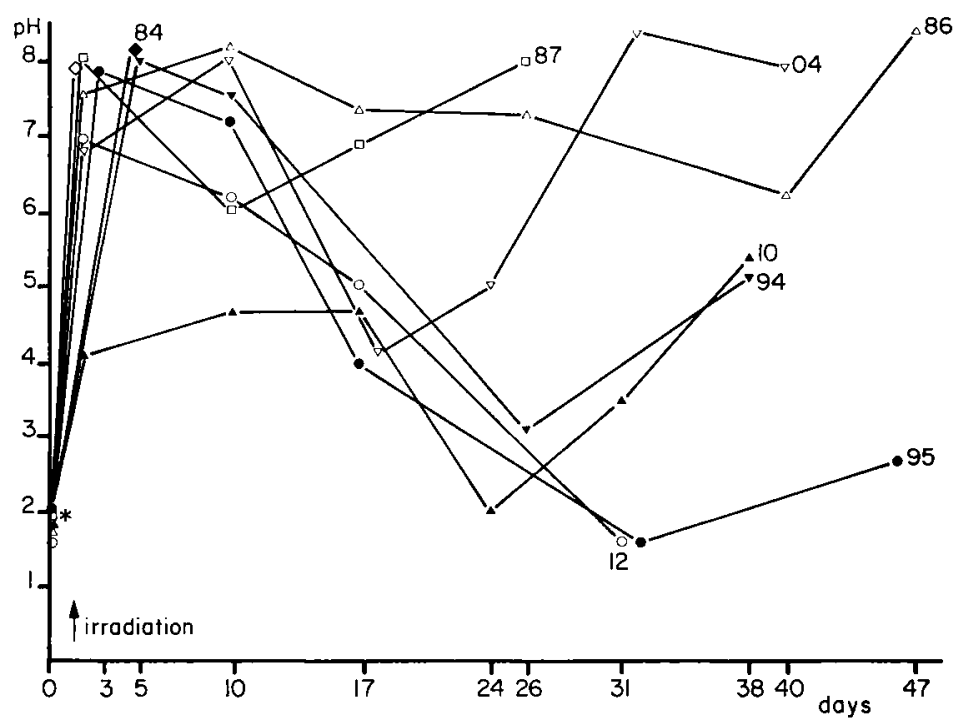

FIG. 2. - Pattern of gastric juice $\mathrm{pH}$ in 8 irradiated pigs after pentagastrin.

The secretion patterns showed individual variation but achlorhydria generally persisted up to day 10 ; the $\mathrm{pH}$ of the following samples dropped to 4 and 5 , and the buffer capacity ratios fell below 1 , indicating that acid secretion was sufficient for

* Amount given per $\mathrm{kg}$ per day : volume $45 \mathrm{ml}$, kcal 42, proteins $1.65 \mathrm{~g}$, Na $1.62 \mathrm{meq}$, $\mathrm{K} 1 \mathrm{meq}$. 
diminishing acid deficiency, but not enough to markedly increase total acidity and induce free acidity. Alkaline secretion augmented considerably : buffer capacity rose from 8.6 to values ranged between 30 and $90 \mathrm{meq} / \mathrm{l}$.

It was mentioned above that duodenal reflux is normal in swine, but the presence of bile did not appear to markedly affect the chemical characteristics of stomachal secretion. There was no correlation in this study between approximate bile salts content and the $\mathrm{pH}$ of gastric juices sampled after gastrin stimulation. On the other hand, there was a significant correlation with sodium ion content.

In the same samples, we found a positive correlation between sodium ion concentration and buffer capacity (or $\mathrm{pH}$ ). There was no correlation between DNA and potassium concentrations.

Pepsin. - The mean concentration in controls after stimulation was $10.2 \mathrm{mg} / \mathrm{ml}$ \pm 0.48 for $\mathrm{pH}$ 's between 1.65 and 1.8. There was a very significant correlation $(r=0.80$ for 73 samples) between the $\mathrm{pH}$ and the pepsin content of gastric juices. When the $\mathrm{pH}$ was higher than 2.5, pepsin concentration fell to between 3 and 5.5 $\mathrm{mg} / \mathrm{ml}$; with a $\mathrm{pH}$ between 7.5 and 8 , it was less than $0.5 \mathrm{mg} / \mathrm{ml}$.

DNA rate. - The mean rates, measured on samples 3 to 6 , were of the same magnifude as those cited by Croft and Lubran (1965) and Domschke et al., (1977) in humans (table 1). A very significant rate (and concentration) peak appeared at about day 25 after irradiation and a significant rise was noted in the last samples (38 to 46 days).

TABLE 1

Mean DNA rates (based on samples 3 to 6)

\begin{tabular}{|c|c|c|c|c|c|c|c|}
\hline & $\mathrm{T}=\mathrm{DO}$ & D3 & D10-12 & D17 & D24-26 & D32 & D38-46 \\
\hline $\begin{array}{l}\operatorname{Rate} \ldots \ldots \ldots \ldots \ldots \ldots \\
\gamma / \min \ldots \ldots \ldots \ldots \ldots\end{array}$ & 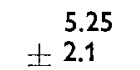 & $\begin{array}{r}7.8 \\
\pm 1.3\end{array}$ & $\begin{aligned} & 5.24 \\
+ & 2.3\end{aligned}$ & $\begin{array}{r}7.5 \\
\pm 3.2\end{array}$ & $\begin{array}{l}26.9 * \\
\pm 10.2\end{array}$ & $\begin{array}{r}7.1 \\
\pm 1.6\end{array}$ & $\begin{array}{l}16.4^{*} \\
\pm \quad 9.5\end{array}$ \\
\hline
\end{tabular}

* Significant at $\leqslant 5$ p. 100.

TABLE 2

Glycemia pattern (in percentage of zero time value) after induced hyper and hypoglycemia tests (mean of 8 controls). Glycemia at TO $=66 \pm 4.6 \mathrm{mg} / 100 \mathrm{ml}$

\begin{tabular}{|c|c|c|c|c|c|c|c|c|}
\hline Time in minutes & & 0 & 2 & 7 & 15 & 30 & 60 & 120 \\
\hline Hyperglycemia (p. 100)... & \pm & $\begin{array}{c}100 \\
10.3\end{array}$ & $\begin{array}{c}310 \\
15.5\end{array}$ & $\begin{array}{r}241 \\
11\end{array}$ & $\begin{array}{r}153 \\
27\end{array}$ & $\begin{array}{c}112 \\
27.8\end{array}$ & $\begin{array}{r}108 \\
27\end{array}$ & $\begin{array}{r}107 \\
14\end{array}$ \\
\hline Hypoglycemia (p. 100). . & \pm & $\begin{array}{r}100 \\
12\end{array}$ & $\begin{array}{r}101.5 \\
10.5\end{array}$ & $\begin{array}{l}98.4 \\
13\end{array}$ & $\begin{array}{l}76.3 \\
18.4\end{array}$ & $\begin{array}{l}61 \\
14\end{array}$ & $\begin{array}{l}66.7 \\
19\end{array}$ & $\begin{array}{l}85.6 \\
15\end{array}$ \\
\hline
\end{tabular}


D. - Exploration of the endocrine pancreas. As an aid to estimating the modifications caused by irradiation, we have visualized the patterns of glycemia and insulinemia (as percentage of zero time) in the induced hyper and hypoglycemia tests on 8 controls (tables 2, 3).

\section{TABLE 3}

Insulinemia patfern (in percentage of zero time value) ofter induced hyper and hypoglycemia (mean of 8 controls). Insulinemia at TO $=30.4 \pm 9.4 \mathrm{uU} / \mathrm{ml}$.

\begin{tabular}{crrrrrrrr}
\hline Time in minutes & 0 & 2 & 7 & 15 & 30 & 60 & 120 \\
\hline Hyperglycemia (p. 100)..... & & 100 & 379 & 398 & 339 & 130 & 133 & 125 \\
& \pm & 38 & 92 & 102 & 133 & 28 & 96 & 56 \\
\hline Hypoglycemia (p. 100)...... & & 100 & 233 & 168 & 129 & 92 & 72 & 89 \\
& \pm & 47 & 43 & 46 & 54 & 26 & 16 & 32
\end{tabular}

Glycemia after irradiation.

a) After induced hyperglycemia, the $K$ factor (slope of the blood decrease curve) declined gradually from day 10 (fig. 3 ) to one-quarter of the control value $\left(4.07 \times 10^{-2}\right)$ at days 46 to 50 .

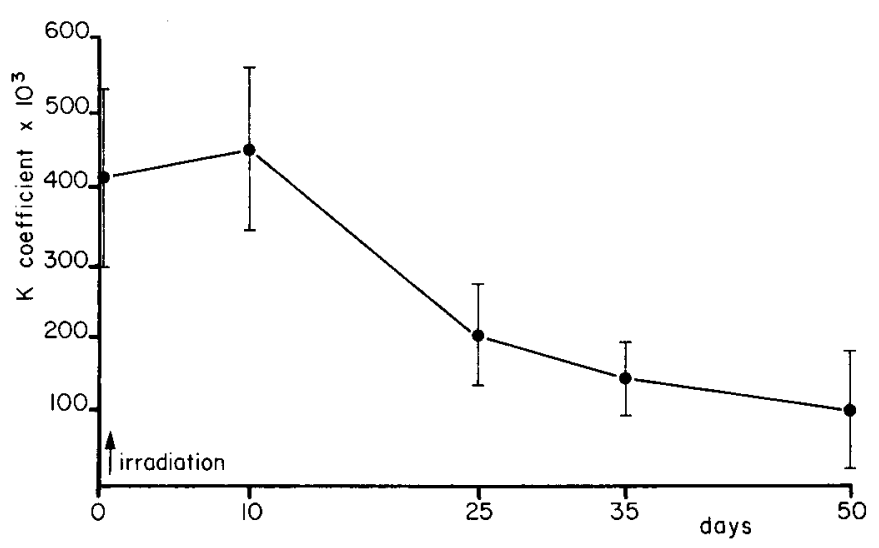

FIG. 3. - Slope of induced hyperglycemia curve (K coefficient) after irradiation.

b) After tolbutamine-induced hypoglycemia. Table 4 shows the mean percentages of glycemia at 30,60 and $120 \mathrm{~min}$, using zero time (TO) as a reference. The return to normal was progressively delayed.

c) Basal glycemia (measured on fasting animals at zero time in tests of induced hyper and hypoglycemia) increased regularly after irradiation and, the last days, reached a significant value ( $>5$ p. 100) which was 30 p. 100 higher than the control value. 
TABLE 4

Glycemia pattern after induced hyper and hypoglycemia with folbutomide (in percentage of zero time value) (means of 6 irradiated animals)

\begin{tabular}{|c|c|c|c|c|}
\hline $\mathrm{T}(\mathrm{min})$ & 0 & 30 & 60 & 120 \\
\hline 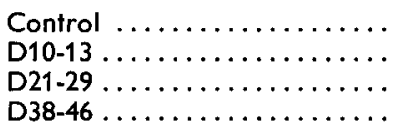 & 100 (p. 100) & $\begin{array}{l}61 \\
55.7 \\
70.9 \\
59\end{array}$ & $\begin{array}{l}66.7 \\
58.2 \\
62 \\
58.6\end{array}$ & $\begin{array}{l}85.6 \\
71.8 \\
74.3 \\
59\end{array}$ \\
\hline
\end{tabular}

Insulinemia. - The mean maximum values after hyperglycemia are given in percentage of the value at zero time in table 5. Only the mean value at days 24-25 differed significantly from that of the controls; however, some sluggishness in response was apparent (control maximum at 2-5 min; maximum in irradiated animals at $15 \mathrm{~min}$ ).

TABLE 5

Maximum insulinemia after induced hyperglycemia (in percentage of zero time value) (means of 6 irradiated animals)

\begin{tabular}{rrrrr}
\hline & $T$ & $D 10-12$ & $D 24-29$ & $D 34-55$ \\
\hline$m$ & & & & \\
& +398 & 400 & $260^{*}$ & 374 \\
& \pm 102 & \pm 101 & \pm 119 & \pm 158 \\
\hline
\end{tabular}

* Significant at 5 p. 100.

After hypoglycemia, a similar response was obtained with a maximum at $2 \mathrm{~min}$; this value was approximately $300 \mathrm{p} .100$ of that of the controls, and remained constant at days 10-12, 24-27, and 38-40, but then shifted gradually to $15 \mathrm{~min}$.

E. - Gastrinemia. At $30 \mathrm{~min}$ after vagal stimulation (tolbutamide-induced hypoglycemia), gastrinemia had increased by $34 \mathrm{p.} 100$ in the controls $(51.6 \pm 8.7 \mathrm{~g} / \mathrm{ml})$. There was no peak after irradiation.

The pattern of basal gastrinemia after irradiation (sampling at TO) was the following : in 5 out of 7 animals, gasirinemia was 2 to 6 times higher from day 20, and increased regularly from then until death.

F. - Exocrine pancreas. The changes in the apparent feed digestibility of the irradiated animals was estimated by studying the nutritional balances (Daburon et al., 1978) and the fecal composition (Sautier, 1973). These values were compared to 
those found for the same diets after pancreatic duct ligature. We studied 2 adult Corsican pigs for more than 500 days after the operation, but did not observe (as Corring and Bourdon, 1977, studying young Large-White pigs) digestive compensation, although, from a nutritional viewpoint, they tolerated the operation well (no weight loss).

The nutritional balances from days 20 to 55 after irradiation are shown in table 6 . The protein retention ratio did not vary significantly among the three groups. Except for sodium, apparent digestibilities were very similar in ligatured and irradiated animals : the sodium flux towards the intestinal lumen increased in the mucosa of the irradiated ones, and absorption decreased (Goodner et al., 1955).

\section{TABLE 6}

Nutritional balances 20 to 55 days after irradiation.

\begin{tabular}{|c|c|c|c|c|c|c|c|}
\hline \multicolumn{4}{|c|}{ Digestibility } & \multirow{2}{*}{$\frac{\begin{array}{c}\text { Reten- } \\
\text { tion }\end{array}}{\mathrm{N}}$} & \multicolumn{3}{|c|}{$\begin{array}{c}\text { Net } \\
\text { utilization }\end{array}$} \\
\hline & $\mathrm{DM}$ & $O M$ & $N$ & & $\mathrm{Na}$ & $\mathrm{Ca}$ & $\mathbf{P}$ \\
\hline $\begin{array}{l}\text { Controls }(10) \ldots \ldots \ldots \ldots \\
\text { Pancreatic ligature (9) } \ldots \ldots \ldots \\
\text { Irradiated (8)........ }\end{array}$ & $\begin{array}{l}80.6 \\
73.2 * * * \\
71.1 * *\end{array}$ & $\begin{array}{l}83.1 \\
75.7 * * * \\
75 * *\end{array}$ & $\begin{array}{l}79.2 \\
56.1 * * * \\
61.8 * * *\end{array}$ & $\begin{array}{l}44 \\
41.8 \\
50\end{array}$ & $\begin{array}{c}15.5 \\
11.9 \\
0\end{array}$ & $\begin{array}{l}27.6 \\
16.1 * * \\
12 *\end{array}$ & $\begin{array}{l}31.6 \\
20.9 * * \\
21 * *\end{array}$ \\
\hline
\end{tabular}

* Significant at $\leqslant 5$ p. 100 .

** Significant at $\leqslant 1$ p. 100 .

*** Significant at $\leqslant 1$ p. 1000 .

Fecal composition is shown in table 7. Total and soluble protein levels were similar in ligatured and irradiated pigs, however they were more perturbed in the former. On the other hand, mineral levels varied inversely in the two groups.

TABLE 7

Variation in fecal composition (in percentage of control composition) (control concentration $=100$ p. 100).

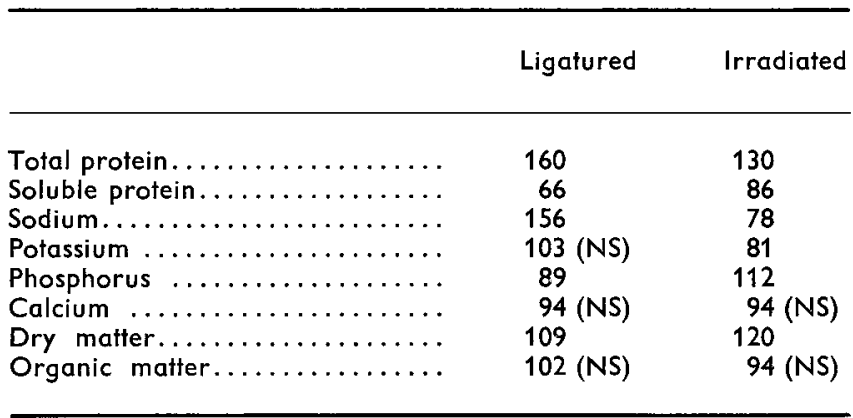




\section{Discussion.}

The method of gastric intubation with an indwelling catheter is simple to apply and permits overall exploration of the stomachal secretions, but in the pig salivary contamination cannot be avoided when the animal is conscious. Moreover, enzyme and protein levels in the gastric juices cannot be measured. The small stomach method of Pavlov, studied by Remy ef al. (1975) during short survival (a few days) after $1500 \mathrm{rd}$, is too traumatic to use in long-term research on animals irradiated at $1100 \mathrm{rd}$.

Median survival of the 8 Corsican pigs was clearly lower than in the Pitman Moore lots studied previously (Daburon ef al., 1978), although the causes of mortality were analogous : the irradiation dose was the same but the profective plates were placed further back (just below the xiphoid process) and dose intensity was lower by a factor of about 2.5. The Corsican pigs in the present work seemed definitely more radiosensitive.

Since the work of lvy in 1923, we have been aware that achlorhydria results after gastric irradiation. More recently, Murray et al., (1969) reported that it was necessary to use at least 1750 rd on the rat stomach to cause permanent achlorhydria ; after 1 000-1 $250 \mathrm{rd}$, he observed, as we did in swine, a preliminary phase of achlorhydria during the first 2 weeks, followed, during the next weeks, by a very irregular return to normal, punctuated with periods of hyposecretion. Only one of our animals (95) regained its secretory functions; while voluntary oral feeding, although capricious, was still possible with $\mathrm{pH} 3$ to 5 , anorexia was complete at $\mathrm{pH} 7$ to 8 .

The peak of DNA appearing in the gastric juices towards days 24 to 26 , along with differences in cell renewal kinetics, confirmed the results of Brecher ef al. (1958) on the dog and of Capoferro (1974) on the guinea-pig: maximum lesions occurred in the dog between weeks 2-3 and in the guinea-pig between weeks 3-5. When the development of intestinal and stomachal lesions in swine are compared, maximal histological disturbance is seen to occur between days 9 and 13, while fecal protein concentration is maximum on day 11 (Daburon ef al., 1975, 1979) (fig. 4).

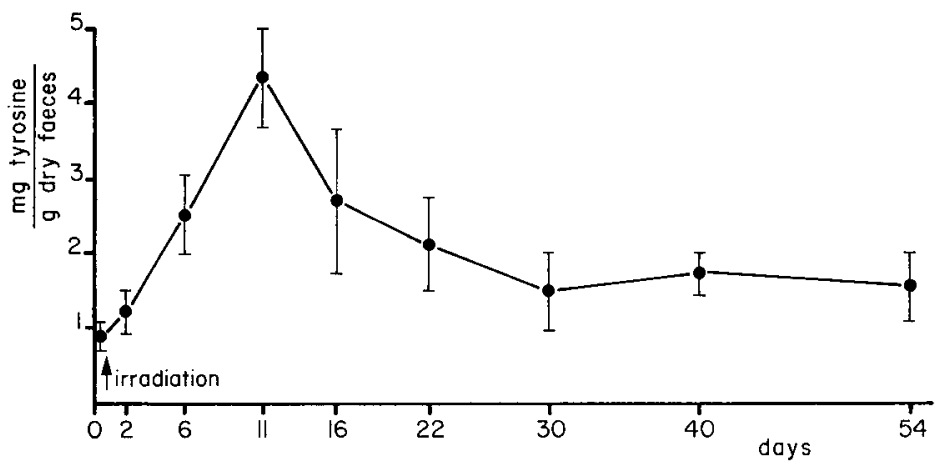

FIG. 4. - Pattern of exudative protein concentration in the feces (in $\mathrm{mg}$ of tyrosine).

The gradual pancreatic atrophy we observed previously (Daburon ef al., 1978) led to a prediabetic state characterized by : 
1) constant decline of the $K$ factor, i.e. of the rate of cell trapping and the utilization rate of the intravenously injected sugar;

2) the trend of the induced hypoglycemia curve showing no return to initial value at $120 \mathrm{~min}$;

3) a more than 30 p. 100 increase in basal glycemia after 1 month of survival.

However, according to the insulinemia curves, insulin secretion was little affected, and there was no glycosuria.

The change in the apparent feed digestibility is the result of three processes : (i) poor digestion due to hypopancreatism (ii) poor absorption owing to functional deficiency of the intestinal mucosa and (iii) increased protein loss in the lumen of the digestive tract. Modification in exocrine secretion could only be detected by the significant decrement of soluble proteins in the feces and by comparing the balances of ligatured and irradiated animals. Daburon ef al. (1978) reported that after the first month, with the dose of irradiation used, the animals became progressively hypopancreatic.

The increased loss of fecal sodium and decreased calcium absorption are the consequences of intestinal deficiency. The low net utilization of phosphorus is due both to increased fecal and urinary loss (Daburon et al., 1978).

Increased intestinal protein loss confirmed by chronic exudative enferitis (Chomette ef al., 1977), is clearly evidenced on the curve of figure 4 : after the peak at day 11 , fecal mean protein content stabilized to about 50 p. 100 above the normal.

Finally, the disappearance of the peak of gastrinemia at $30 \mathrm{~min}$ indicated that vagal stimulation induced by hypoglycemia did not cause antral cell secretion. However, these cells appeared to have retained their secretory ability because gastrinemia increased progressively from day 20 , reaching very high levels, while gastric juice $\mathrm{pH}$ rose above 5 (fig. 2). Although we did not note any significant correlation between $\mathrm{pH}$ and gastrinemia, gastric hypoacidity might stimulate gastric secretion.

Irradiation apparently affected vagal stimulation but not that induced by gastric content hypoacidity.

\section{Conclusion.}

Irradiation-induced hypochlorhydria appears to be the main factor in the anorexia observed in swine irradiated in the abdominal region. While the symptoms of secretory disorder were similar in all the animals, its ulterior progress varied greatly, phases of recovery alternating with periods of inhibition.

The endocrine pancreas was clearly affected : insulin secretion continued to respond to stimulation by induced hyper and hypoglycemia, but tissular utilization of glucose, or its glycogen accumulation, seemed to be highly modified.

The exocrine pancreas secretions decreased gradually, aggravating the poor intestinal absorption and the intestinal protein loss. Apparent feed digestibility decreased, but not in a way compatible with middle-term survival.

Stomachal mucosa response to gastrinic stimulation was very perturbed.

Reçu en juillet 1979.

Accepté en novembre 1979. 
Acknowledgements. - We are greatly indebted to P. A. Villiers for help with the surgical techniques and to J. Carmarans and F. Dacher for the animal care.

Résumé. Les sécrétions gastriques et pancréatiques ont été étudiées chez 8 porcs irradiés à 1100 rd sur la moitié postérieure du corps.

L'irradiation entraîne régulièrement une achlorhydrie qui dure au moins 10 jours ; la récupération, partielle et très variable selon les sujets, conditionne étroitement la réalimentation ou la persistance de l'anorexie. La réponse de la muqueuse stomachale à la stimulation gastrinique est très perfurbée.

L'atteinte de la fonction endocrine du pancréas conduit à l'installation progressive d'un état diabétique ; la fonction exocrine semble également diminuer dans le temps de la survie. Bien que s'ajoutant à la malabsorption et à la fuite protéique intestinale, ces déficits fonctionnels ne paraissent pas influencer de façon dramatique sur la survie à moyen terme.

\section{References}

BERGSTROM S., DANIELSSON H., GORANSSON A., 1959. On the bile acid metabolism in the pig. Acta chem. scand., 13, 776-783.

BRECHER G., CRONKITE E. P., CONARD R. A., SMITH W. W., 1958. Gastric lesions in experimental animals following single exposures to ionizing radiations. Am. J. Pathology, 34, 105112.

CAPOFERRO R., 1974. A scanning electron microscopie study of normal and $X$ irradiated guineapig gastric mucosa. Scand. J. Gastroent., 9, 533-38.

CHOMETTE G., DABURON F., AURIOL M., GARNIER H., 1977. Irradiation à forte dose de l'intestin grêle chez le porc. Etudes histoenzymologique et ultra-structurale. Virchows Arch. B. cell. Path., 23, 237-256.

CORRING T., DABURON F., REMY J., 1975. Effet de l'irradiation aiguë sur la sécrétion du pancréas exocrine chez le porc. Strahlentherapie, 149, 417-425.

CORRING T., BOURDON D., 1977. Exclusion of pancreatic exocrine secretion from intestine in the pig : existence of a digestive compensation. J. Nutr., 107, 1216-1221.

CROFT D. N., LUBRAN M., 1965 . The estimation of deoxyribonucleic acid in the presence of sialic acid : application to analysis of human gastric washings. Bioch. J., 35, 612-620.

DABURON F., CHOMETTE G., REMY J., VILLIERS P. A., GREGOND J. C., TRICAUD Y., SEVIGNAC M., HAAG J., 1975 . La restauration de l'intestin chez le porc irradié à forte dose. Biol. Gastroenterol. (Paris), 8, 321-338.

DABURON F., DUEE P. H., TRICAUD Y., BOURHOVEN D., MARION CI., 1978. Bilans nutritionnels chez le porc irradié à forte dose (1 $100 \mathrm{rd}$ ) sur la moitié postérieure du corps. Ann. Biol. anim. Bioch. Biophys., 18, 651-662.

DABURON F., VILLIERS P. A., FAGNIEZ P. L., HAY J. M., TRICAUD Y., BOURHOVEN D., 1979. Research on the therapeutics of intense abdominal irradiation in pig. Rad. envir. Biophys., 17, 67-83.

DEVAUX G., 1970. Exploration fonctionnelle de l'estomac, 338-343. In Choix de Techniques de Biochimie classique, Gauthier-Villars, Paris.

DOMSCHKE W., DOMSCHKE S., HAGEL J., DEMLING L., CROFT D. M., 1977. Gastric epithelial cell turnover, mucus production, and healing of gastric ulcers with Carbenoxolene. Gut., 18, 817-820.

GOODNER C. I., MOORE T. E., BOWERS J. Z., ARMSTRONG W. D., 1955. Effects of acute whole body X-irradiation on the absorption and distribution of $\mathrm{Na}_{22}$ and $\mathrm{H}_{3} \mathrm{OH}$ from the gastrointestinal tract of the fasted rat. Am. J. Physiol., 183, 475-484.

HASLEWOOD G. A. D., 1964. The biological significance of chemical differences in bile salts. Biol. Rev., 39, 537-574.

IVY A. C., ORNDOFF B. H., JACOBY A., WHITLOW J. E., 1923. Studies of the effect of X-Rays on glandular activity. III. The effect of $X$-Rays on gastric secretion. Radiology, 1, 39-46. 
JACQUOT R., LE BARS H., SIMONNET H., 1958. Nufrition animale, Vol. 1, Données générales sur la nutrition et l'alimentation, 337, J. B. Baillière et Fils, Paris.

KLOTZ A. P., DUVALL M. R., 1957. The laboratory determination of pepsine in gastrine juice with radioactive iodinated albumin. J. Lab. clin. Med., 50, 753.

MURRAY M. J., STEIN N., MATHEWS J., DEYO R., 1969. Production of achlorhydria in rats by direct irradiation of the stomach. Proc. soc. Exp. Biol. Med., 131, 737-739.

PE THEIN M., SCHOFIELD B., 1959. Release of gastrin from the pyloric antrum following vagal stimulation by sham, feeding in dogs. J. Physiol. (London), 148, 291-305.

REMY J., DABURON F., VILLIERS P. A., DUBEDAT P., 1975. Effets de l'irradiation aiguë d̀ dose létale sur la sécrétion gastrique chez le porc. Strahlentherapie, 150, 532-538.

RUBIN P., CASARETT G. W., 1968. Clinical radiation pathology. a) Vol. 1, chap. 5, 153-192. b) Vol. 1, chap. 7, 241-292. W. B. Saunders Co Philadelphia, London, Toronto.

SAUTIER C., 1973. Etude quantitative des fécès, 125-149. In OLIVIER H. R., Traité de biologie appliquée. Tome V, Chap. II, Maloine, Paris.

SZALKOWSKI C. R., MADER W. J., 1952. Colorimetric defermination of desoxycholic and in ox bile. Analyt. Chem., 24, 1602-1604.

ZEITOUN P., 1965. Examens complémentaires en gastro-entérologie. Rev. Praticien, 15, 197-220. 